\title{
ARTYKUŁY
}

Klio. Czasopismo poświęcone dziejom Polski i powszechnym PL ISSN 1643-8191, t. 27 (4)/2013, s. 129-149

(c) $(1)$

DOI: http://dx.doi.org/10.12775/KLIO.2013.052

Mateusz MaleszKa

(Toruń)

\section{Biblijna argumentacja $w$ dyskusji o separacji rasowej i niewolnictwie czarnych w USA w drugiej potowie XIX wieku}

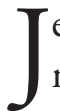
ednym z najważniejszych skutków wojny secesyjnej było zniesienie niewolnictwa w stanach południowych. Sytuacja społeczna uległa daleko idącym przemianom. Czarna ludność Południa stała się wolna i uzyskała status obywateli. Na Północy zaś następowała migracja czarnej ludności do miast w poszukiwaniu pracy, która tworzyła konkurencję dla niewykwalifikowanej białej siły roboczej. Sąsiedztwo czarnych środowisk stawało się dla białych obywateli problemem, nawet dla dotychczasowych zwolenników wolności i równości. Dla wielu białych wizja równych praw ludności kolorowej i białej wydawała się nie do pomyślenia. Argumentów potwierdzających teorie o wyższości rasy białej nad kolorowymi szukano zarówno w sferze „naukowej”, jak i w religii.

Część amerykańskich protestanckich teologów z XIX wieku usiłowała znaleźć w Biblii uzasadnienie dla porządku społecznego akceptującego niewolnictwo czarnych. Interpretując fragment Księgi Wyjścia ${ }^{1}$ : ss. 1440 .

1 Wszystkie cytaty biblijne podane za: Biblia Tysiąclecia, wyd. 3, Poznań 1980, 
Ja Pan, twój Bóg, jestem Bogiem zazdrosnym, który karze występek ojców na synach do trzeciego i czwartego pokolenia względem tych, którzy Mnie nienawidzą"2,

doszli do wniosku, że kolor skóry i niewolnictwo jest karą za przewinienie popełnione przez jednego z ich przodków. Tak jak Bóg pokarał Żydów za ukrzyżowanie Chrystusa zburzeniem świątyni jerozolimskiej i zniszczeniem Izraela, tak przodkowie ciemnoskórych musieli dopuścić się innego czynu odrażającego w oczach Pana.

W efekcie uznania czarnych za niegodnych, różne zbory protestanckie opowiadały się za utrzymaniem segregacji rasowej lub wręcz utrzymaniem instytucji niewolnictwa. Spór o zgodność instytucji niewolnictwa z Biblią był jedną z głównych przyczyn odłączenia się tzw. południowych baptystów w południowych stanach ${ }^{3}$. Również Kościół Jezusa Chrystusa Świętych w Dniach Ostatnich, choć sprzeciwiający się instytucji niewolnictwa od wczesnych lat swego istnienia, przestrzegał zasad odseparowania ludności kolorowej od białej. Nawet w postępowych zborach (jak w Pleasant Grove nieopodal Hinesville w Georgii czy Pierwszy Kościół Prezbiteriański w Darien $)^{4}$, w których w nabożeństwach uczestniczyć mogli i biali, i kolorowi, przestrzegano zasady odseparowania. Czarni, nie mogąc uczestniczyć w pełni w życiu religijnym, zmuszeni zostali do założenia własnych związków wyznaniowych - National Baptist Convention czy African Methodist Episcopal Church ${ }^{5}$. Zdaniem wielu konserwatywnych południowych duchow-

2 Wj 20, 5.

3 Baptyści szczególnie akcentują autonomię poszczególnych zborów, w efekcie czego różnią się często między sobą w pewnych kwestiach np.: predestynacja bądź wolna wola, pewność bądź możliwość utracenia zbawienia, stosunek do teorii ewolucji. Południowi baptyści zrzeszeni w Konwencji Południowych Baptystów (Southern Baptist Convention) są obecnie największym związkiem zborów baptystycznych w USA. Z racji szerokiej autonomii różne zgromadzenia mogą w sposób odmienny interpretować Pismo Święte. Jeszcze w latach pięćdziesiątych XX wieku, zdarzały się przypadki, że południowi baptyści w Missisipi nauczali o osobnym raju dla białych i kolorowych. (C. Murdock, Land of Till Murder, „Ebony”, 1956, nr 4, s. 91).

4 S. M. Stowe, Potudnie, [w:] Historia Stanów Zjednoczonych, t. 2, Warszawa 1995, s. 285 .

5 H. Sitkoff, Stosunki rasowe w Stanach Zjednoczonych 1917-1945, [w:] Historia Stanów Zjednoczonych, t. 4, Warszawa 1995, s. 343. 
nych, odrzucających hasła wolności i choćby częściowego równouprawnienia kolorowych głoszone przez licznych abolicjonistycznych kaznodziejów z Północy, instytucja niewolnictwa miała swoje biblijne pochodzenie i nie należało jej znosić. Prezbiterianin James Henley Thornwell posunął się wręcz do twierdzenia, że powołaniem Kościoła nie jest budowanie społeczeństwa na nowo ${ }^{6}$.

\section{Preadamityzm ${ }^{7}$}

W 1891 roku William Campbell napisał rozprawę Anthropology for the People: A Refutation of the Theory of the Adamic Origin of All Races. Zwrócit w niej uwagę na fakt, że na 1,400 mld ludzi żyjących w jego czasach, 1,050 mld stanowić mieli ludzie „ras gorszych”, niezdolnych stworzyć cywilizacji. Doszedł więc do wniosku, że nie jest możliwe, by biali i kolorowi pochodzili od tego samego przodka. Dowodził dwóch możliwych rozwiązań. Pierwsze z nich zakładało pochodzenie wszystkich ludzi od biblijnych rodziców, co oznaczało, że większość ludzkości uległa daleko idącej degeneracji czy też dewolucji (teoria monogenezy). Alternatywna teza zakładała istnienie innych ludzi żyjących obok Adama i Ewy (teoria poligenezy) ${ }^{8}$. Dowodów na istnienie ludzi w czasach poprzedzających biblijną chronologię dostarczyła autorowi nauka.

Już w połowie XIX wieku geolodzy i archeolodzy znajdowali dowody na to, że Ziemia jest starsza niż 6000 czy 10000 lat $^{9}$ (a takie liczby uzyski-

6 S. M. Stowe, op. cit., s. 284.

7 Preadamici mieli być pradawnymi mieszkańcami ziemi żyjącymi obok rajskich ogrodów Edenu. Wśród nich w krainie Nod miał się schronić przed ojcem Kain. Wierzenie w istnienie owych preadamitów było traktowane przez Kościół jako herezja. O ludziach żyjących obok biblijnego Adama pisał Giordano Bruno i tworzący w XVII wieku holenderski drukarz Izaak La Perreyre. Według niego potomkami Adama miał być naród wybrany, a biblijni bałwochwalcy mieli być preadamickiego pochodzenia. (H. Masson, Stownik herezji w Kościele katolickim, Katowice 1993, s. 253).

8 W. Campbell, Anthropology for the People: A Refutation of the Theory of the Adamic Origin of All Races, Richmond 1891, s. 17-19.

9 Zwolennicy teorii kreacjonistycznych dzielą się na zwolenników młodego lub stare- 
wali znawcy Biblii, sumując ze sobą lata życia patriarchów). Znajdowanie śladów obecności człowieka na Ziemi starszych niż biblijna chronologia pozwoliło postawić tezę, że obok Edenu istniały inne cywilizacje. Ponieważ cywilizacje te nie pochodziły od Adama, nie wpływały one - zdaniem Campbella - na chronologię biblijną ${ }^{10}$.

Campbell wykorzystywał również teorię ewolucji do potwierdzenia swoich tez. Zwracał wprawdzie uwagę, że ewolucjoniści niejednokrotnie zapominali o wierze w Boga, lecz nie przeszkadzało mu to w wykorzystaniu ich wkładu naukowego w swych rasistowskich teoriach. Szczególnie często przytaczane są prace profesora Thomasa Henry'ego Huxleya ${ }^{11}$ o pochodzeniu białej ludności. Według Huxleya dzisiejsza dominująca na świecie ludność miała być potomkami dwóch grup ludności, wywodzących się z północy Xanthochroi (jasna cera i jasne włosy) oraz Melanochroi (jasna cera i ciemne włosy), dominujących w basenie śródziemnomorskim, na Bliskim Wschodzie i w Indiach. To właśnie tym grupom ludności pisana jest hegemonia na Ziemi ${ }^{12}$.

Skoro Bóg stworzył człowieka na swój obraz i podobieństwo oraz oddał mu ziemie we władanie, a biali ludzie jednoznacznie dominują, to oczywistym wnioskiem według Campbella jest to, że Adam był biały. Kolor skóry zaś jest jedynie dowodem na to, że Bóg uczynił ludzi nierównymi, a białym

go wieku Ziemi. Do grona tych pierwszych zaliczyć należy zwolenników datowania dokonanego przez Jamesa Usshera (1581-1656), określającego datę stworzenia na 4004 p.n.e., Denisa Pétau (1583-1652), datującego stworzenie na rok 3983 p.n.e., oraz Henry’ego Fynes Clintona (1781-1852), szacującego na 4138 p.n.e. Zwolennicy starego wieku Ziemi zakładają, że Ziemia ma ponad 5000 czy 10000 lat. Wśród badaczy, którzy stworzyli ten pogląd, należy wymienić dr. Halesa, szacującego stworzenie Ziemi na rok 5411 p.n.e., czy rachubę dr. Poole'a, ustalającą stworzenie na rok 5421 p.n.e. Dziś zwolennicy tego poglądu skłaniają się do zdania, że wiek Ziemi zbliża się 10000 lat. (L. Hoyle, The Pre-Adamite, or who tempted Eve?, Philadelphia 1875, s. 7).

10 W. Campbell, op. cit., s. 29.

11 Thomas Henry Huxley (1825-1885) był brytyjskim propagatorem teorii Darwina. Huxley napisał swe pierwsze dzieło poświęcone ewolucji człowieka Evidence as to Man's Place in Nature już w roku 1863. Sformułował w nim tezę, że proces ewolucji dotyczy również rodzaju ludzkiego. Jego poglądy spotkały się z zaciętą krytyką duchowieństwa anglikańskiego.

12 T. H. Huxley, Man's Place in Nature, [b. m.] 1894, s. 233. 
dał pierwszeństwo nad resztą ludzkości. Skoro Stwórca uczynił ludzi nierównymi, nie należy w żaden sposób traktować kolorowych na równi z białym społeczeństwem ${ }^{13}$. Ponadto, jakakolwiek działalność misyjna i edukacyjna wśród kolorowych skazana jest z góry na niepowodzenie. Według Campbella nie mógł się narodzić czarnoskóry poeta czy naukowiec, jeśli nie miał ani odrobiny domieszki białej krwi. Działalność misyjna ${ }^{14}$ wśród ludności mongoloidalnej ograniczać się miała jedynie do niektórych kast społecznych, zainteresowanych chrześcijaństwem raczej jako fenomenem kulturowym niż zbawieniem duszy ${ }^{15}$. W dalszej części argumentacji Campbell zwracał uwagę, że biblijny Kain szukał schronienia przed karą za zabójstwo Abla właśnie wśród ludzi niepochodzących od Adama. Azyl znalazł w krainie Nod leżącej na wschód od Edenu. Dzięki wiedzy, którą przekazał tym ludziom, powstały cywilizacje kolorowych w różnych krańcach świa$\mathrm{ta}^{16}$. Niepisane było im przetrwać konfrontacji z białym człowiekiem. Dla tego autora niższość rasowa kolorowych nie była jednak karą, lecz efektem tego, że Bóg stworzył niebiałych w innym celu.

Poza Campbellem, łączącym biblijne studia ze zdobyczami nauki, jeszcze kilku zwolenników białej dominacji głosiło słuszność nierówności rasowych, opierając się na domniemanym preadamickim pochodzeniu ludności kolorowej. Jednym z nich był Lester Hoyle, który w 1875 roku napisał książkę The Pre-Adamite, or who tempted Eve? Autor wyróżnił pięć ras ludzkich - mongoloidalną, negroidalną, malajską, białą i rasę Indian amerykańskich. Już w pierwszym rozdziale książki założył, że nie jest możliwe, by taka różnorodność osób pochodziła od jednego przodka sprzed 4 czy 5 tys. lat ${ }^{17}$. Autor powtarzał tezy Huxleya i Darwina o podobieństwie między małpą a człowiekiem, jednocześnie odrzucał jakąkolwiek tezę ewolucji. Otóż, w świetle formułowanych przez niego tez, ze wszystkich ras ludzkich

13 W. Campbell, op. cit., s. 157.

14 W XIX wieku pojawiały się jeszcze bardziej radykalne opinie. Uważano między innymi, że Murzyni są bliżsi zwierzętom niż ludziom i próby ich nawracania stanowią ciężki grzech. Taki pogląd został poruszony w liście zaadresowanym do znawcy Biblii niejakiego McGarveya. (Ch. Carroll, The Negro a Beast or In the Image of God, [b. m.] 1900, s. 375).

15 W. Campbell, op. cit., s. 162.

16 Ibidem, s. 135.

17 L. Hoyle, op. cit., s. 7. 
Bóg najwcześniej stworzył czarnoskórych, prawdopodobnie razem z małpami, do których są podobni. Po czarnych Bóg powołać do życia miał kolejno: Malajów, Indian i mongoloidów. Dopiero na samym końcu białego człowieka ${ }^{18}$. Hoyle bardzo dowolnie wybierał to, co należy traktować w Biblii dosłownie, a co metaforycznie. Tytułowa Ewa była postacią realną, a jej kuszenie było już metaforą. Ewy nie miał skusić wąż - bo węże wszak nie mówią, a nawet gdyby mówiły, byłyby dla Ewy obrzydliwe. Kusicielem był przedstawiciel rasy mongoloidalnej - piękny i bystry przodek Chińczyków ${ }^{19}$. Warto pamiętać, że na lata siedemdziesiąte XIX wieku, kiedy Hoyle pracował nad swoją książką, przypada początek amerykańskiego strachu przed „żółtym zagrożeniem”. Pierwsi Chińczycy trafili do USA w okresie kalifornijskiej gorączki złota, która wybuchła po wojnie z Meksykiem. Zwiększająca się liczba taniej chińskiej siły roboczej podczas rozbudowy sieci kolejowej wywoływała zaniepokojenie białej ludności. Antychińskie uprzedzenia skutkowały nie tylko lokalnymi pogromami chińskich robotników, ale i wprowadzeniem prawnej dyskryminacji chińskiej ludności przez Page Act z 1878 roku $^{20}$ oraz Chinese Exclusion Act z 1882 roku $^{21}$.

Hoyle zwracał uwagę na fakt, że przedstawiciele kolorowych ras nie zawsze są dla białych ohydni i odpychający. Dlatego właśnie Ewę mógł oczarować mongoloid, tak samo jak Cezara i Marka Antoniusza uwiodła

18 Ibidem, s. 17-19.

19 Ibidem, s. 23-24.

20 Był to pierwszy amerykański dokument ograniczający możliwość imigracji do USA. Pozbawione jej zostały (rzekomo niemoralne) azjatyckie kobiety, co miało obniżyć rozrodczość chińskiej populacji. Dokument ten wprowadzał również sankcję karną (do 2000 \$ i aż do roku pozbawienia wolności) za sprowadzanie żółtych robotników do prac przymusowych wbrew ich woli. Ten akt prawny był pierwszym federalnym dokumentem określającym jedną z grup ludności jako niepożądaną.

${ }_{21}$ Ten niewielki akt prawny utrudniał imigrację nowych przybyszy z Azji do Stanów. Wymagana była zgoda od chińskich władz na wyjazd do USA. Zakazywał on również imigracji niewyszkolonej i wyszkolonej siły roboczej, chcącej znaleźć zatrudnienie w górnictwie na okres dziesięciu lat. Dla Azjatów, którzy opuścili USA i pragnęli powrócić do Stanów, akt ten prezentował szereg utrudnień ( $\mathrm{w}$ tym powtarzania od nowa procedury umożliwiającej przyjazd). Dokument ten w praktyce uniemożliwił naturalizację azjatyckich mieszkańców USA. 
Kleopatra, a Johna Rolfa - Pocahontas ${ }^{22}$. Również przypowieść o potopie była dla Hoyle’a alegorią. Uważał za niemożliwe zniszczenie całego istnienia przez jeden deszcz. Zwracał uwagę, że na kontynencie amerykańskim żyją dzikie zwierzęta, które nie mogłyby dotrzeć do góry Ararat przez morza i oceany. Pozwoliło mu to wnioskować, że w jakiś sposób również inne grupki ludzi poza Noem i jego rodziną przetrwały potop ${ }^{23}$. Inną próbą uzasadnienia przetrwania preadamickich społeczności jest hipoteza, że Noe na swą arkę zabrał także przedstawicieli innych ras ludzkich, a po ustąpieniu wód potopu umieścił ludzi i zwierzęta na krańcach Ziemi ${ }^{24}$. Odseparowanie ludzi o innym pochodzeniu niż potomkowie Adama miało zapobiec potopowi na przyszłość, ponieważ dla Hoyle’a, interpretującego w swój specyficzny sposób ustęp:

synowie Boga, widząc, że córki człowiecze są piękne, brali je sobie za żony wszystkie, jakie im się podobały ${ }^{25}$,

potop był karą za grzech zmieszania się z preadamitami. Dla Hoyle’a spadkobiercami Adama oraz Noego, Chama, Sema i Jafeta byli tylko biali ludzie. Jednakże rasa ta była, jego zdaniem, kalana relacjami seksualnymi z gorszymi ludźmi. Słowianie mieli być już skażeni krwią mongolską, co odróżniło ich od nomadycznego szczepu Abrahama, który przed mongoloidami „nie ugiął kolan”26. Rozważania nad „psuciem się” białej rasy nie zajmują wiele miejsca w książce Hoyle’a, dlatego nie można ich porównać z pracami niemieckich ariozofów (takich jak tworzący koncepcje teozoologii Jörg Lanz von Liebenfels ${ }^{27}$ ), ogarniętych wręcz obsesją na punkcie przenikania elementów azjatyckich do białej rasy.

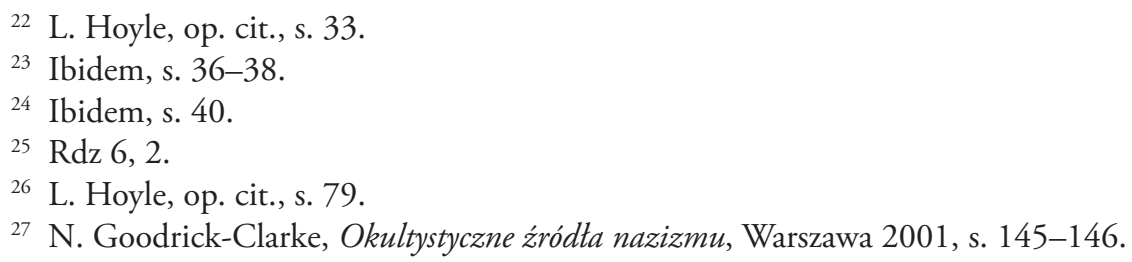




\section{Znamię Kaina}

Argumentem często podnoszonym wśród zwolenników preadamickiego pochodzenia kolorowych ras jest przytaczana wyżej biblijna historia Kaina, szukającego schronienia przed karą w krainie Nod położonej na wschód od Edenu. Kain spłodził tam liczne potomstwo, które opanowało sekrety metalurgii. Według Hoyle’a Kain dał początek cywilizacji turańskiej, której zdolności zbliżały się do zdolności reszty potomstwa Adama ${ }^{28}$. William Campbell twierdził, że od Kaina pochodziły wszystkie niebiałe cywilizacje, włącznie z upadłymi cywilizacjami Majów i Azteków ${ }^{29}$. Podobną opinię wyraził Alexander Winchell, autor dzieła Adamites and Preadamites. Uważał on, że to potomkowie Kaina założyli cywilizację azjatycką prawie tak rozwiniętą, jak europejska. Na szczególnie zaawansowanym poziomie rozwoju miała być cywilizacja turańska, pochodząca od Adamitów i przodków Mongołów $^{30}$.

Interpretatorom Starego Testamentu intrygujący wydał się fragment mówiący o znamieniu Kaina. Dla niektórych badaczy, w tym dla mormońskiego przywódcy Brighama Younga (1801-1877), znamię Kaina miało oznaczać, że skóra bratobójcy zmieniła kolor na czarny. Dopiero od jego potomstwa mogli wywodzić się negroidzi. Przekonanie to było powszechne w USA w XVIII i na początku XIX wieku. Koncept pochodzenia czarnoskórych od Kaina był wręcz tak powszechny, że pojawia się w wierszu On being brought from Africa to America pierwszej murzyńskiej poetki, Phillis Wheatley ${ }^{31}$. Jeszcze w 1900 roku Charles Carroll w książce The Negro a Beast or In the Image of God udowadniał, że czarni pochodzą od małp, z którymi współżył Kain, gdyż żadna córka Adama nie zbliżyłaby się do człowieka naznaczanego przez Boga specjalnym znamieniem ${ }^{32}$. Według Carrolla kolejne pokolenia dzieci Kaina były płodne i miały dać początek „Murzyno-

${ }^{28}$ L. Hoyle, op. cit., s. 136.

29 W. Campbell, op. cit., s. 135.

30 A. Winchell, Adamites and Preadamites, Syracuse N. Y. 1878, s. 26.

31 P. Wheatley, Poems on Various Subjects, Religious and Moral, London 1773, s. 18: Remember, Christians, Negroes, black as Cain, May be refin'd, and join th' angelic train.

32 Ch. Carroll, op. cit., s. 145-147. 
wi - najniższej z tak zwanych ras ludzkich"33. Dowodem na pochodzenie czarnych od Kaina miała być niemożność stworzenia czarnej cywilizacji. Zdaniem tego autora w miarę rozrostu społeczności czarnoskórych ginęły w niej szlachetne wartości i umiejętności syna Adama, potęgowała się zaś skłonność do przemocy i brutalności odziedziczona po Kainie ${ }^{34}$. Do takiego wniosku przywiodła go interpretacja słów Lameka, potomka Kaina:

Jeśli Kain pomszczony miał zostać siedmiokrotnie, to Lamek pomszczony będzie siedemdziesiąt siedem razy ${ }^{35}$.

Sam Carroll przedstawił historię braci Kaina i Abla odmienną od tradycyjnego wyobrażenia. Kainowi, jako pierworodnemu, za żonę miała przypaść pierwsza córa Adama i Ewy. Kain był jednak lubieżnym człowiekiem i nie zamierzał czekać, aż siostra się urodzi i osiagnie dojrzałość, by być gotową do zawarcia związku małżeńskiego. Nie mogąc się doczekać, zaczął współżyć z bestiami. Widząc, że „piękna, dziewicza i niewinna” siostra w wyniku boskiego nakazu przypadła Ablowi, znienawidził brata i go

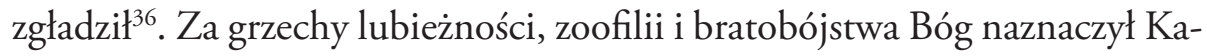
ina znamieniem ${ }^{37}$. Autor był tak pewny swych tez, że przedstawiał dowody obalające odmienne twierdzenia. Jego zdaniem analogicznie do faktu, że nie ma możliwości, by z jaja indyczego wykluła się kaczka, a z jaja gołębiego wykluł się kruk, nie było możliwe, aby od białych rodziców Adama i Ewy pochodzili czarnoskórzy ${ }^{38}$. Z charakterystyczną dla siebie spostrzegawczością zauważał, że jeśli od biblijnych rodziców pochodziliby czarni, istniałoby stałe ryzyko urodzenia się czarnoskórych dzieci ze związku białych rodziców ${ }^{39}$. Carroll odrzucił, jako niedorzeczną, tezę wywodzącą rodowód czarnych od Chama, syna Noego. Sądził, że niemożliwe było, aby Noe miał

\footnotetext{
33 Ibidem, s. 149.

34 Ibidem, s. 229.

$35 \mathrm{Rdz}$ 4, 24.

36 Ch. Carroll, op. cit., s. 145-146.

$37 \mathrm{Rdz} 4,13-14$.

38 Ch. Carroll, op. cit., s. 268.

39 Ibidem, s. 226.
} 
autorytet i moc nakazania swym wnukom, aby stały się czarnymi, by kochający Bóg zaakceptował aż tak straszną klątwę pijanego Noego, oraz, że czyn, którego dopuścili się Cham z Kanaanem, nie był tak straszny, aby na wieki wypaczyć umysł i ciało ${ }^{40}$. Sugestię, jakoby czarni - gdyby żyli w czasach poprzedzających zbudowanie arki - poginęliby w wodach potopu, kontruje argumentem, że Noe zabrał „Murzynów i inne domowe zwierzęta” na pokład swego statku ${ }^{41}$. Poza niezgodnością z pismem i nienaukową teorią o chamickim pochodzeniu czarnoskórych, znawca Biblii atakuje również ewolucjonistów $^{42}$. Przytacza teorie zwolennika darwinizmu, Ernsta Haeckela, o pochodzeniu ludzi od form najprostszych, od ryb i płazów, przez zwierzęta i człowieka niemego (speachless man) lub małpoluda (ape-man), świadomie zaznaczając, że Haeckel przyznaje, że nieodkryte jest jeszcze brakujące ogniwo między człowiekiem a małpą ${ }^{43}$. Carroll odrzuca wszelkie sugestie, jakoby Murzyn pochodził od tych samych małpoludów, od których wywodzi się człowiek. Za absurdalne przyjmuje założenie, że z czarnych wyodrębnili się Malajowie, z nich Indianie, z najbystrzejszych Indian Mongoloidzi, od których z kolei pochodzić mieli najdoskonalsi biali. Odrzuca nawet „racjonalny” dowód, że skoro ewolucja polega na udoskonalaniu, to naturalne jest „odbarwianie” kolejnych generacji przodków człowieka aż po dzisiejszego białego ${ }^{44}$. Ateistyczne teorie ewolucjonistów są - zdaniem Carrolla - nie tylko niezgodne z Pismem, lecz również sprzeczne ze zdrowym rozsądkiem. Założenie, że biały człowiek jest najlepszą z ras ludzkich, a czarny - najgorszą, jest błędne. Ateiści źle interpretują naukowe odkrycia: czarny nie miał być najgorszym spośród ludzi, lecz najdoskonalszą z małp. Dowodem na to mają być kształty „murzynokształtnych” (negro-like) małp - szympansów, orangutanów i goryli ${ }^{45}$. Dla prawdziwego chrześcijanina oczywiste jest, że człowiek nie pochodzi od zwierząt, gdyż św. Paweł zazna-

\footnotetext{
${ }^{40}$ Ibidem, s. 75-77.

${ }^{41}$ Ibidem, s. 170.

42 Ibidem, s. 81.

43 Ibidem, s. 83.

${ }^{4}$ Ibidem, s. 84 .

45 Ibidem, s. 87.
} 
czył, że ciało ludzkie różni się od zwierzęcego ${ }^{46}$. Wspólne korzenie zwierzyny i ludzi były więc niemożliwe. Potomstwo Kaina i „bestii” pozbawione jest duszy ${ }^{47}$. Jedynie ciało z ciała Adama ma duszę, wszystkie inne stworzenia mające ciało (zwierzęta, ryby i ptaki) duszy nie posiadają. Pozbawione jest jej też potomstwo Kaina i tych białych, którzy współżyli z czarnymi. Ponieważ nie można mieć jedynie części duszy, mulaci są jej pozbawieni w takim samym stopniu jak czarni. Według Carrolla wystarczyła jedna kropla $\mathrm{krwi}^{48}$, by potomstwo nie miało duszy ${ }^{49}$.

Wraz z upływem czasu teoria o pochodzeniu czarnoskórych od bratobójczego syna Adama nie wytrzymywała krytyki ani dosłownych interpretatorów Biblii (którzy uważali, że wody potopu zgładziły potomstwo Kaina), ani pseudonaukowców pokroju Campbella czy Hoyle’a, traktujących Biblię z większym dystansem.

\section{Pochodzenie od Chama}

Alternatywną i najmocniej zakorzenioną w powszechnej świadomości biblijną koncepcją pochodzenia rasy czarnej było wywodzenie jej od syna

461 Kor 15, 39.

${ }^{47}$ Ch. Carroll, op. cit., 139.

48 W niektórych stanach południowych wprowadzona została w XX wieku zasada „one drop blood”. Oznaczała ona, że osoba, w której żyłach płynęła choćby kropla czarnej krwi, czyli miała choćby jednego czarnego przodka, pozbawiona była możliwości zawarcia związku małżeńskiego z białym. Prawo to jako pierwsze wprowadzono w stanach Tennessee i Luizjana. Inne stany miały bardziej liberalne ustawodawstwo. Zakazywano w nich małżeństw z osobami mającymi co najmniej jednego dziadka (zasada jednej czwartej) lub pradziadka (zasada jednej ósmej) czarnego. Szczególnie interesujący jest przypadek stanu Virginia, w którym w 1924 r. wydano „The Racial Integrity Act” zakazujący białym małżeństw z niebiałymi. Niebiałych definiowano jako mających choćby kroplę krwi czarnej albo ponad jedną szesnastą krwi indiańskiej. Wnioskodawca projektu, Walter Ashby Plecker, proponował wprowadzenie wartości jednej sześćdziesiątej czwartej krwi indiańskiej, okazało się to jednak niemożliwe. Zważywszy jednak, że wielu senatorów stanu Virginia szczyciło się wręcz pochodzeniem od miejscowych rodów indiańskich (w tym księżniczki Pocahontas), zastosowano „bardziej liberalny” ułamek: jednej szesnastej krwi indiańskiej (E. Black, Wojna silnych przeciw stabym, Warszawa 2004, s. 259-261).

49 Ch. Carroll, op. cit., s. 157. 
Noego, Chama ${ }^{50}$. Cham i jego syn Kanaan zostali przeklęci za naigrywanie się z pijanego Noego. Zdaniem wielu „badaczy” Biblii przekleństwo rzucone na Chama i Kanaana miało polegać na zmianie koloru skóry, a słowa Noego

niech będzie przeklęty Kanaan! Niech będzie najniższym sługą swych braci! ${ }^{12}$

miały sankcjonować niewolnictwo. Na liczne skojarzenia Chama z kolorem czarnym wpływał m.in. fakt, że w biblijnych Psalmach Egipt określa się krainą Chama ${ }^{52}$. Dodatkowo imię to- zdaniem niektórych „ekspertów” miało znaczyć tyle co czarny ${ }^{53}$. Do grona takich „znawców” Biblii zaliczali się, tworzący pod pseudonimem Ariel, Buckner Payne oraz skłaniający się do tej teorii pastor Thornton Stringfellow.

Stringfellow był głęboko religijnym baptystą, tworzącym w okresie poprzedzającym wojnę secesyjną. Celem jego działalności było pogodzenie instytucji niewolnictwa z wartościami chrześcijańskimi. W książce Scriptural and Statistical Views in Favor of Slavery - po interpretacji przekleństwa, które rzucił Noe - stwierdził, że posiadanie niewolników jest moralne i słuszne, gdyż służy większemu dobru ${ }^{54}$. Potomkowie Jafeta (Żydzi oraz Europejczycy) mieli prawo niewolić synów Chama i Kanaana tak długo, jak postępowali w zgodzie z boskimi nakazami. Spadkobiercom Jafeta miał je

50 Pogląd ten nie ograniczał się do wyznawców jedynie doktryny protestanckiej. Takiemu przekonaniu hołdował od średniowiecza cały świat chrześcijański, a jeszcze w XIX wieku muzułmanie, nawet niektórzy broniący instytucji niewolnictwa Żydzi (jak mieszkający na południu Stanów rabin Morris Jacob Raphall). W 1862 r. jeden z najlepiej wykształconych czarnoskórych swej epoki, pastor Alexander Crummell, stwierdził, że pogląd o pochodzeniu czarnych od Chama jest powszechny praktycznie w całym chrześcijańskim świecie (D. B. Davis, Inhuman Bondage: The Rise and Fall of Slavery in the New World, Oxford 2006, s. 63-67).

$51 \mathrm{Rdz} 9,25$.

52 Ps 105, 23-27; Ps 106, 21-22.

53 B. Payne, The Negro: What is His Ethnological Status?, Cincinnati 1877, s. 4.

${ }_{54}$ T. Stringfellow, Scriptural and Statistical Views in Favor of Slavery, Richmond 1856, s. 8-10. 
podyktować Mojżesz ${ }^{55}$. Pastor zauważył, że Nowy Testament ${ }^{56}$ nie tylko nie nawołuje do zniesienia niewolnictwa, lecz również nakazuje niewolnikom posłuszeństwo wobec panów ${ }^{57}$. Podkreślał, że posiadanie licznych sług było dla patriarchów synonimem bogactwa ${ }^{58}$. Według wielebnego niewolnictwo miało zbawienny wpływ na ludność Stanów Zjednoczonych. Dostarczało nie tylko bogactwa (i to zarówno mieszkańcom Południa, jak i Północy), lecz miało również chronić społeczeństwo przed przestępczością. Zdaniem Stringfellowa w stanach, w których dopuszczalne było niewolnictwo, przestępczość była niższa. W samym tylko więzieniu w Nowym Jorku miało być osadzonych tyle samo skazańców co w całych stanach niewolniczych razem wziętych ${ }^{59}$. Południe było rzekomo bogatsze dzięki systemowi niewolnictwa, a zjawisko pauperyzacji ludności miejskiej na nim nie występowało ${ }^{60}$. Beneficjentami niewolnictwa mieli być, zdaniem autora, sami czarni. Standard życia w niewoli, według pastora, był wielokrotnie wyższy niż standard życia dzikich w Afryce. Stringfellow zaznaczał ponadto, że życie w niewoli na Południu jest znacznie łatwiejsze niż życie i ciężka praca na Północy. Wolni Murzyni pracują ciężej, więcej i gorzej się odżywiają, z tej też przyczyny nie należy się dziwić licznym, zdaniem Stringfellowa, przypadkom, gdy zbiegli niewolnicy błagają białych na Północy o odesłanie ich na Południe $^{61}$.

Według Bucknera Payne’a twierdzenie o pochodzeniu czarnych od Adama i Ewy nie było prawdą. Nie było nią również twierdzenie, że dzisiejsi czarni zostali stworzeni przed białymi. Jego zdaniem kluczem do wyjaśnienia genezy czarnoskórych jest prawidłowe zrozumienie historii o Noem i Chamie. Payne dopuszcza (zgodnie z prawda) ${ }^{62}$, że imię może mieć inne

$55 \operatorname{Kpt~25,~44-46.~}$

$561 \operatorname{Tm} 6,1-2$.

57 T. Stringfellow, op. cit., s. 49.

58 Ibidem, s. 16.

59 Ibidem, s. 142.

60 Ibidem, s. 145.

61 Ibidem, s. 139-140.

${ }^{62}$ Dziś lingwiści zajmujący się językiem hebrajskim tłumaczą imię Cham jako „gorący" (Z. Pasek, Bogowie demony herosi, Kraków 1996, s. 90). 
znaczenie niż czarny, np. opalony czy gorący ${ }^{63}$. Ponadto zauważa, że imiona braci Chama - Sema i Jafeta - nie są określeniami koloru ${ }^{64}$. Zwraca uwagę, że potomstwo Chama stworzyło wiele miast i wspaniałych cywilizacji, takich jak Egipt zbudowany przez drugiego syna Chama, Misraima, czy Sydon założony przez Sydona, syna Kanaana ${ }^{65}$. Te wielkie cywilizacje nie mogłyby być zbudowane rękoma czarnych i upadły nie dlatego, że władali nimi nieudolni kolorowi władcy, lecz dlatego, że Bóg przeznaczył władzę nad światem białemu potomstwu Jafeta ${ }^{66}$. Źródeł pochodzenia czarnych należy więc szukać nie w popularnej teorii wywodzącej murzyński ród od potomstwa przeklętego Chama, lecz gdzie indziej. Payne dochodzi w ten sposób do wniosku, że czarni to bestie bez duszy, zabrane przez Noego na $\operatorname{arkę~}^{67}$. Podpatrzywszy ludzkie osiągnięcia, czarni po opuszczeniu arki mieli rozplenić się na Ziemi aż po Indie. Szczególną rolę w ekspansji czarnoskórych miał odegrać jeden z potomków Chama. Nimrod ${ }^{68}$ był prawnukiem Noego, wnukiem Chama i synem Kusza. Choć był wspaniałym łowcą, był też nikczemnym despotą. To właśnie za jego rządów próbowano wznieść wieżę Babel. Payne tłumaczy to okrutne bałwochwalstwo tym, że Nimrod i jego ojciec nie byli wolni od przedpotopowych grzechów (miał na myśli współżycie z bestiami, czyli Murzynami) i nie wyrzekłszy się swych skłonności po potopie, nadal im folgowali, prowadząc jeszcze grzeszniejszy żywot. Rozejście się ludzi po zburzeniu wieży Babel spowodowało również rozproszenie haremu Nimroda ${ }^{69}$.

Obsesja na punkcie demoralizującego wpływu stosunków seksualnych białych z kolorowymi widoczna jest także u innych interpretatorów Biblii. Zdaniem Hoyle'a kolejne pokolenia kolorowych są coraz bardziej zdziczałe i prymitywne. Potomkowie bratobójcy Kaina są, według niego, jeszcze okrutniejsi, całkowicie zatracają swe białe dziedzictwo ${ }^{70}$.

\footnotetext{
${ }^{63}$ B. Payne, op. cit., s. 9.

${ }^{64}$ Ibidem, s. 5.

${ }^{65}$ Ibidem, s. 12.

${ }^{66}$ Ibidem, s. 25.

${ }^{67}$ Ibidem, s. 45.

$68 \mathrm{Rdz} 10,9-10$.

69 B. Payne, op. cit., s. 31.

${ }^{70}$ L. Hoyle, op. cit., s. 29.
} 
Rozważania o cywilizacjach stworzonych przez niebiałych ludzi nie były obce innym protestanckim zwolennikom wyższości białej rasy. Campbell wielokrotnie zaznaczał, że nie jest możliwe, by tak ważne postacie z Afryki jak Hannibal, Kleopatra, Saladyn czy św. Augustyn miały w sobie choćby kroplę murzyńskiej krwi ${ }^{71}$. Z tej też przyczyny starał się wykazać, że potomstwo Chama było białe. Hoyle z potomkami Chama usiłował identyfikować społeczności Fenicjan, Egipcjan, Berberów, Chaldejczyków i Maurów oraz współegzystujących z czarnymi Nubijczyków i Etiopczyków, bardziej wartościowych od wszystkich innych czarnych, lecz nadal gorszych od potomstwa Jafeta ${ }^{72}$. Bardziej radykalny pogląd prezentował Charles Carroll. Według niego wszystkie rasy powstałe w wyniku mieszania się krwi murzyńskiej z białą - Azjaci, mieszkańcy Oceanii, Indianie, a nawet Lapończycy, Finowie i Baskowie ${ }^{73}$ - nie są zdolne stworzyć samodzielnie wielkiej cywilizacji. To ocaleli z wód potopu potomkowie Adama, jako koloniści z czasów Noego, wznieśli wszystkie wielkie budowle w Ameryce Środkowej i Południowej, a przyczyną upadku tych cywilizacji było oddanie się rozpuście i zmieszanie się z potomkami kolorowej ludności ${ }^{74}$. Tezy o pochodzeniu wielkich starożytnych cywilizacji od białego człowieka Carroll zaczerpnął z $\operatorname{prac}^{75}$ Arthura de Gobineau ${ }^{76}$. Różnił się jednak w ocenie tych cywilizacji

71 W. Campbell, op. cit., s. 220.

72 L. Hoyle, op. cit., s. 9.

${ }^{73}$ Ch. Carroll, op. cit., s. 168.

${ }^{74}$ Ibidem, s. 173-175.

75 Ibidem, s. 100.

76 Arthur de Gobineu (1816-1882) wyróżnił dziesięć wielkich cywilizacji. Cywilizacja indyjska, powstała w wyniku podboju subkontynentu indyjskiego przez białą ludność. Cywilizacja egipska, panująca nad Nubijczykami i Etiopczykami, założona przez białych kolonistów nad ujściem Nilu. Cywilizacja asyryjska (do której zaliczał Fenicjan, Kananejczyków, Arabów, Hebrajczyków i Kartagińczyków), będąca owocem mieszania się ludności wywodzącej się od legendarnego Sema i Chama. Największy rozkwit tej cywilizacji miał nastąpić pod panowaniem białych Persów i Medów. Cywilizacja grecka, będąca cywilizacją aryjską, zmieszaną ze śródziemnomorskimi wpływami semickimi. Cywilizacja chińska, powstała w podobny sposób co cywilizacja egipska, lecz wykształciła się ona w wyniku absorpcji przedstawicieli rasy malajskiej, nie zaś czarnej. Cywilizacja z Półwyspu Apenińskiego, łącząca ze sobą pierwiastki aryjskie, semickie, greckie i śródziemnomorskie. Aryjska i biała cywilizacja germańska. Trzy ostatnie zaś to cywilizacje amerykańskie. Cywilizacja 
od Francuza, odrzucał bowiem twierdzenie, że w wyniku przemieszania się ludności powstała nowa rasa o ściśle zdeterminowanych cechach. Zamiast tego Carroll założył, że ludy te skazane są na upadek.

\section{Mormoni i czarnoskórzy}

Specyficzny stosunek do osób o czarnym kolorze skóry i do niewolnictwa prezentowali w XIX wieku członkowie Kościoła Jezusa Chrystusa Świętych w Dniach Ostatnich, zwani potocznie mormonami. Odrzucali oni niewolnictwo i możliwość posiadania jednego człowieka przez drugiego na własność uznawali za grzech, jednocześnie jednak zwracali uwagę na pochodzenie czarnoskórych od Kaina. Powodowało to w mormońskiej wspólnocie jawną stygmatyzację osób o tym kolorze skóry. Aż do 1978 roku praktycznie nie przyjmowano osób o tym kolorze skóry do stanu kapłańskiego. Mormoni wierzą, że przemawiający przez proroków Bóg nakazał Lehiemu wyprowadzić grupę Izraelitów z Azji do ziemi obiecanej w Ameryce. Księga Mormona opisuje dzieje potomków Lehiego - zatracających wiarę Lamanitów i wiernych boskiej prawdzie Nefitów - którzy przybyli na ziemie dzisiejszego USA już w V wieku przed Chrystusem. W Księdze Mormona brakuje odniesień do „znamienia Kaina”, które mieli nosić na sobie czarni. Zamiast tego Druga Księga Nefiego zawiera scenę, w której grupa synów Lamana sprzeciwia się boskiej woli głoszonej przez Nefiego. Bóg pokarał ich w następujący sposób ${ }^{77}$ :

„alleghańska”, oznaczająca ludy indiańskie Ameryki Północnej. Cywilizacja mezoamerykańska oraz cywilizacja peruwiańska (m.in. Inkowie). Gobineu uważa, że spośród pierwszych siedmiu cywilizacji aż sześć powstało dzięki białemu człowiekowi. Cywilizacja asyryjska zaś zawdzięcza Aryjczykom swój renesans. Uważa on, że nie mogły powstać prawdziwe cywilizacje bez ingerencji białego człowieka (choć nie jest pewny co do możliwego wpływu cywilizacji amerykańskich). Carroll był bardziej radykalny, przedstawiał nawet archeologiczne dowody na pobyt białej ludności w Ameryce prekolumbijskiej. (A. Gobineu, The Inequality of Human Races, London 1915, s. 212).

77 Wszystkie przytoczone fragmenty Księgi Mormona pochodzą z wydania Księga Mormona - Jeszcze Jedno Świadectwo o Jezusie Chrystusie, Intellectual Reserve, Inc. 1981, ss. 524 . 
I doświadczył ich srogim przekleństwem z racji ich niegodziwości, bo znieczulili swe serca przeciwko Panu, że stały się one niczym głaz, dlatego jak byli oni biali, piękni i mili dla oka, aby nie byli pokusą dla naszych, Pan Bóg sprawił, że ich skóra stała się ciemna, tak powiedział Pan Bóg: Spowoduję, że będą wstrętni dla twoich, jeśli nie nawrócą się odstępując od nieprawości ${ }^{78}$.

Ta sama księga zawiera jednocześnie zapewnienia, że w oczach Boga wszyscy ludzie są równi:

On Nikomu, którzy przystąpią do Niego, obojętnie czy jest czarnoskórym czy białym, niewolnikiem czy wolnym, mężczyzną czy kobietą [...], pamięta On też o innych narodach, i wszyscy są jednakowo traktowani przez Boga, zarówno Żydzi, jak i przedstawiciele innych narodów ${ }^{79}$.

Litościwy Bóg nie skazał potomków Lamana na wymarcie, lecz pozwolił im dożyć współczesności. Nakazał jednak ściśle przestrzegać podziałów rasowych i zabronił utrzymywania relacji seksualnych z czarnoskórymi. Czarni mieli być zarazem dowodem na miłosierdzie Boga oraz ostrzeżeniem przed grzechem:

I uczynił ich, aby potomstwo odróżniało się od potomstwa ich braci. W ten sposób Pan Bóg zachował swój lud, by nie mieszali się z nimi i nie uwierzyli w złe tradycje, które doprowadziłyby do ich zagłady ${ }^{80}$.

Odseparowani od Nefitów brzydcy potomkowie Lamana stali się ludźmi czarnoskórymi lub przodkami Indian.

Warto pamiętać, że w stanie Utah już w XIX wieku funkcjonował zakaz zawierania związków małżeńskich między białymi a kolorowym. Przepisy penalizujące zawieranie takich małżeństw zostały uznane za niekonstytucyjne przez Sąd Najwyższy dopiero w 1967 roku $^{81}$.

782 Nefi 5:21-22.

792 Nefi 25:33.

80 Alma 3:8.

81 Lovnig v. Virginia 388 U.S. 1 (1967). W tym wyroku Sąd Najwyższy uznał, że rok pozbawienia wolności za zawarcie związku małżeńskiego przez czarnoskórą Mildred 
W Księdze Mormona brakuje twierdzeń sugerujących pochodzenie czarnych od Kaina czy Chama. Sugestie takie pojawiają się jednak już u drugiego z mormońskich przywódców, Brighama Younga. W mowie z 5 lutego 1852 roku wyraził on swoje stanowisko odnośnie do kwestii niewolnictwa. Instytucja niewolnictwa została przez niego potępiona, acz spotkała się z pewnym zrozumieniem. Niewolnictwo miało być konsekwencją grzechu pierworodnego i powinno zniknąć wraz z tym, ,jak prawi ludzie zaczną walczyć ze złem, budując na ziemi nowe królestwo niebieskie”. Czarnoskórzy są zaś potomkami Kaina z Księgi Rodzaju, kolor skóry stanowi ich znamię, lecz nie oznacza to, że biały człowiek powinien wykorzystywać ich pochodzenie. Błogosławieństwem dla białego jest to, że ma czarne sługi i pomocników, ale powinien traktować ich z łaskawością i dobrocią. Jednocześnie Young odrzucił możliwość przyjmowania potomków Kaina do stanu kapłańskiego ${ }^{82}$.

\section{Podsumowanie}

Pierwsze lata okresu tzw. murzyńskiej rekonstrukcji ${ }^{83}$, kiedy zwycięscy republikanie usiłowali wykorzystać czarnoskórą ludność do uczynienia z niej podpory swej władzy na Południu, stanowiły cios dla białej społeczności. Murzyni zdobyli stanowiska wicegubernatorów stanów Luizjana, Karolina Południowa i Missisipi. W Karolinie Południowej udało się im nawet zdobyć na sześć lat większość w niższej izbie legislatury stanowej. Biała ludność Południa zareagowała na te wydarzenia przemocą - w samym tylko Nowym Orleanie w zamieszkach rasowych z 1866 roku zginęło 46 czarnych i dwóch białych. Stopniowo biali południowcy odzyskiwali jednak swe wpływy. Pojawiła się grupa tzw. odkupicieli, których najważniejszym celem

Loving z białym Richardem Lovingiem godzi w konstytucyjną zasadę ochrony wolności obywateli USA zagwarantowaną przez XIV poprawkę konstytucji.

82 http://www.utlm.org/onlineresources/sermons_talks_interviews/brigham 1852 feb5_priesthoodandblacks.htm (źródło internetowe, dostęp: 21.12.2012).

83 B. A. Weisberger, Rekonstrukcja 1865-1877, [w:] Historia Stanów Zjednoczonych, red. A. Bartnicki, t. 3, Warszawa 1995, s. 85. 
prawie zawsze było wyeliminowanie lub co najmniej osłabienie murzyńskiego elektoratu. Cel ten realizowano za pomocą oszustw popełnianych przez białych po przejęciu przez nich kontroli nad lokalnymi komisjami wyborczymi: źle obliczano murzyńskie głosy w sposób niewygodny dla pracujących Murzynów zmieniano daty, miejsca i reguły rejestracji wyborców; stosowano różne kryteria zamieszkania, wykształcenia i wybieralności. Gdy działania takie okazywały się nieskuteczne, dochodziło do aktów przemocy. Mimo że działalność zmierzająca do bezprawnego pozbawienia czarnoskórych wyborców możliwości rejestracji w komisji wyborczej była federalnym przestępstwem, rejestrowano ich coraz mniej ${ }^{84}$. Zwycięstwo demokratów w wyborach w 1874 roku oraz wycofanie wojsk Północy z Południa w 1877 roku umożliwiły powtórne przejęcie władzy przez białe elity i wprowadzenie systemu całkowitej segregacji rasowej w majestacie prawa. Populiści opierający się na uprzedzeniach rasowych doprowadzili do wprowadzenia szeregu praw dyskryminujących czarną ludność. Apelowanie do białej solidarności rasowej miało uniemożliwić współdziałanie białej i czarnej biedoty. Liczne ograniczenia w prawach wyborczych, takie jak testy czytania i pisania, cenzusy majątkowe czy „klauzula dziadka” (zwalniająca z cenzusów wnuków osób, których dziadkowie mieli prawo głosu już przed wojna), spowodowały spadek liczby czarnych wyborców. Między 1897 a 1905 rokiem liczba głosujących czarnych spadła o 44\% ${ }^{85}$. Budowanie solidarności rasowej związane było z postępującą segregacją: nie wpuszczano kolorowych do lokali zarezerwowanych tylko dla białych, prowadzono segregację w środkach transportu, a w Atlancie dla zeznających w sądzie niebiałych przeznaczona była nawet osobna Biblia ${ }^{86}$.

W XIX wieku biała inteligencja usiłowała znaleźć wytłumaczenie takiej organizacji społeczeństwa, która uwzględniałaby stosowanie segregacji rasowej. Nie ograniczano się do odwoływania do darwinizmu społecznego i szukania potwierdzenia w pseudonaukowych wywodach Gobineu, Chamberlaina czy Lapouge’a. Posługiwano się również Biblią jako źródłem uza-

84 Ibidem, s. 86-87.

85 I. Rusinowa, Murzyni i Indianie 1865-1914, [w:] Historia Stanów Zjednoczonych, t. 3, s. 129-131.

${ }^{86}$ H. Sitkoff, op. cit., s. 340. 
sadnienia nierówności ras. Liczni „znawcy” Pisma Świętego usiłowali wykazać biblijną przyczynę niewolnictwa. Wskazywali, że czarni nie są dziećmi Adama i Ewy, są zaś owocem związku biblijnych ludzi z małpami lub pochodzą od bratobójczego Kaina. Pojawiały się też głosy, że są potomkami przeklętego przez Noego Chama lub Kanaana. W ich mniemaniu grzeszny rodowód czarnych uprawniał do odseparowania czarniej społeczności, a nawet sankcjonował niewolnictwo w oczach Boga. Niejednokrotnie radykałowie odmawiali uznania czarnych za ludzi, nazywali ich bestiami czy małpami. Największe obawy budziła jednak perspektywa mieszania się ras kolorowych i rasy białej. Dla poparcia swych racji niejednokrotnie posługiwali się różnymi fragmentami Starego Testamentu. Szczególnie popularne były nakazy i zakazy związane z utrzymywaniem relacji seksualnych z obcoplemieńcami ogłoszone przez Mojżesza. Imaginację Charlesa Carrolla przerastało wyobrażenie sobie duchownego, który mógłby udzielić ślubu parze o różnych kolorach skóry. Według niego lepszym losem dla dziewczyny i jej rodziny byłoby, gdyby spłonęła żywcem, niż związała się węzłem małżeńskim z czarnoskórym ${ }^{87}$. Specyficzna interpretacja biblijnych tekstów stała się jednym ze źródeł amerykańskiego rasizmu, sankcjonującego segregację rasową funkcjonującą w USA aż po lata sześćdziesiąte XX wieku.

\section{A discussion on a Racial Segregation and a Slavery in the United States of America in a Second Half of the $19^{\text {th }}$ Century - Arguments Derived from the Bible}

\section{(Summary)}

In the 19th century White intellectuals were looking for justification of such a social organisation which sanctioned racial segregation. These concepts were fueled not only by the ideology of Social Darwinism and scientific racism, ideas of Gobineu, Chamberlain and Lapouge, but also by the proof of diversity of races recorded in the Bible. Numerous experts attempted to find a cause of slavery in the Bible. They claimed that Blacks are not the posterity of Adam and Eve, but they are either the offspring of humans and apes, or descendants of the first murderer,

${ }^{87}$ Ch. Carroll, op. cit., s. 164. 
Cain, or even descendants of Ham, Noah's cursed son. In the perception of the experts, the sinful origins of Blacks legitimized slavery and segregation. The radicals repeatedly refused to admit that Blacks are human beings, and even used to call them beasts and apes. This strongly biased interpretation of Biblical texts was one of the roots of American racism and racial segregation.

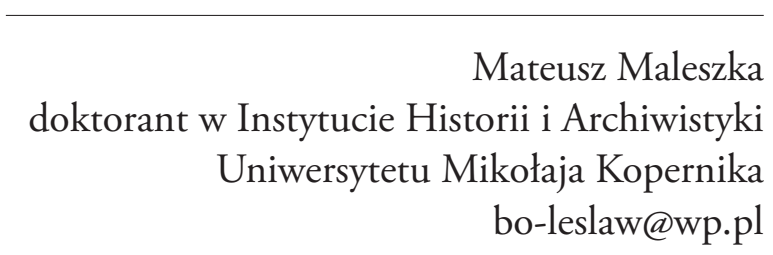

